\title{
ISLAMIC AWAKENING IN INDONESIAN POLITICS, 1990-2004
}

\author{
Lili Yulyadi
}

\section{Introduction}

Islamic awakening in Indonesia would be best explained as a crisis of modernity, which emphasizes the material life, domination of rationalism and reluctance of spiritual dimension. These are significant contributing factors to the Islamic awakening. This could be obviously discerned from the increasing numbers of middle class Muslims who attend religious discourse and commit the religious practices. Nevertheless, this awakening phenomenon can not be separated from the international Muslim revivalism, especially the 1979 Iranian revolution which had successfully brought an Islamic government to power. The event in fact bears witness to the fact that Islam, as political forces is not a passing pad. It yields a moral shield against the "attack" of western "anti-Islam". Finally it acts an anchor for individuals and social groups caught in the tempest of magnitude, relativism, and an identity crisis.

Furthermore, the plight of political and socio-economics of Muslim world provides an ideal breeding ground for its rapid spread. As a result, Afghanistan, the Sudan Islamic governments have been in power since 1992. In Algeria, the electoral victory of the Islamic government forced the traditional bastions and proponents of parliamentary democracy to invoke individual human rights as universal principles of a "higher Order" than the will of majority, thus justifying their open support for military coup.

In Egypt, Morocco, Tunisia, Syria, Iraq, Jordan and other Muslim countries politicized Islam remains an important force to be 
reckoned with. Indonesia as the largest Muslim country in the world also took slightly change in relations with Islam. Since the establishment of ICMI in 1990s, Islam has been accommodated gradually by Suharto's government, and has then played important role in domestic politics during post-Suharto era. This paper attempts to discuss the indicators of Islamic awakening in Indonesian politics. It has been divided into two significant sections; first on the proponents and idea of Islamic awakening; second, it also draws the indicators of Islamic awakening in Indonesia in the early 1990s, which compel the different turn of Islam (the new hope for Islam) in Indonesian politics.

\section{Muslim Proponents and Idea of Islamic Revivalism}

Islamic revivalism is not new issue by the present situation. It goes back to early years upon the demise of the four pious caliphates. Imam Ghazali (1058-1111), for example, was one of the earlier pioneers of Islamic revivalism. In his book "ihya ulumuddin" the revival of religious science", Ghazali provides clear explanation for the necessity of Islamic revival even in an Islamic state. Ghazali who lived in Baghdad during the reign of Sultan Malik Shah -el-Saljouqi, who reigned over vast empire as the defender of the Islamic faith, argued that corruption of the Islamic jurists, the ulama, corrupted the ruling princes and their corruption, in turn, corrupted their subjects and masses. $^{\prime}$

According to Ali Rahnema, Ghazali argued that formal or apparent legal purity veiled intrinsic impurity. What seemed pure on the outside was not on the inside. What was prohibited had become permissible and what was permissible had become forbidden. ${ }^{2}$ Rahnema further asserts that Ghazali mentioned that the greatest part of the wealth, from which the prince gave away gifts to the Jurist consults and functionaries, was ill-gotten or attained and thus it is an Islamically-forbidden manner. ${ }^{3}$ In fact at his time, Ghazali identified ulama and the ruling class as two forces that perpetuated the predicament of the people. His solution was to reform the type of Islam that was upheld and propagated by the official ulama, thereby finding the pure and authentic Islam and changing the people and
finally the ruling elite.

It also was pointed out by Rahnema, that having criticized both actually existing ulama and the political leadership, Ghazali argued that the laws demand obedience to God, His prophet and to those who are in power. Nevertheless, Ghazali abandoned any thought of avoiding the civil war and a 
Rahnema asserts that Ghazali rejected revolutionary change as means of redressing socio-political problems and he considered intellectual dissent and reform as permissible and necessary. ${ }^{5}$ Nevertheless, the modern Islamic revivalists, views the Islamic reeducation of the people as a prelude to revolution and the attainment against unjust un-Islamic rulers. ${ }^{6}$.

All Islamic revivalists are nostalgic about Islam's spirit of compassion, solidarity, fraternity and social justice. This spirit has been associated with the "Golden Age" of the prophet's rule in Medina. As a result, the task of revivalists became one of reconstructing, reforming, reviving or synergizing Islam in order to make it relevant to the needs, demands and predicaments of those whom they considered the victims of modern civilization. They are actually combining a critical discourse of the states with a fall for reconciliation and unity among all Muslims. To confront the outside world and its growing influence, the power and glory of Islam has to be secured by putting an end to the never-ending internal strife between various Islamic sects. Theoretically Islamic revivalists seek to heal previous wounds inflicted by Muslims themselves.?

The product of modern civilization, for Islamic revivalists may be divided into types: the attractive which has to be incorporated and co-opted and repulsive which has to be cleansed and obliterated. On the other hands, the adoption of human rationality as the ultimate source of truth and the total abandonment of divine injunctions is held responsible for social, moral and ethical degeneration and corruption. ${ }^{8}$

In addition, the nature of Islamic revival is neither striking compromises with un-Islamic things, nor preparing new blends of Islam and un-Islamic, but it is cleansing Islam of all un-Godly elements and presenting it and making it flourish more or less in its original pure form. ${ }^{9}$ The revivalists are usually characterized by clear mind, penetrating vision, unbiased straight thinking, special ability to see the right path clear of all extremes and keep balance, power to think independently of the contemporary and centuries old social and other prejudices, courage to fight against the evil of the time, inherent ability to lead and guide and an unusual competency to under take ijtihad and the work of reconstruction. ${ }^{10}$

As such, as Maududi argues that one may analyze the aspects of Islamic revivalists from the 9 elements bellow: one, diagnosis of the current ailments; to examine thoroughly the circumstances and conditions of the time and ascertain exactly where how and what extent "ignorance' has crept in what and where its roots are and what position Islam occupying at the time. Second, scheme of reformation; to determine exactly where to strike the blow so as to 
break the power of un-Islamic and enable Islam to hold of life as a whole. Third, estimation of one's limitations and resources; to weight and estimate at one's disposal and determine the line of action for bringing about reforms. Fourth, intellectual revolution; to shape the ideas, belief and moral view points of the people into Islamic mould, and reform the system of education and revive the Islamic sciences and attitude in general."

Fifth, Practical reform; to eradicate evil customs, cleanse moral, regenerate the spirit of practicing the shari'ah and prepare men capable for Islamic leadership. Sixth, Ijtihad; to comprehend the fundamental principles of religion, judge contemporary culture and its trends from the Islamic viewpoint, and determine the change to be effected in the existing patterns of social life under the shari'ah with a view to attaining its ends and enabling Islam to assume world leadership in the reformed social set-up. Seventh, defense of Islam; to counter political forces seeking to suppress and finish Islam and break their power in order to make Islam a living force. Eighth, revival of Islamic system; to wrest authority from the hands of unIslam and particularly re-establish government on the system described as "caliphate after the pattern of prophet hood" by the holly prophet saw. Finally, universal revolution; not to rest content with establishing the Islamic system in one or more countries already inhabited by the Muslims, but to initiate such a strong universal movements as may spread the reformative and revolutionary message of Islam among the mankind at large, and enable Islam to become a predominant cultural forces in the world and capture the moral, intellectual and political leadership of mankind. ${ }^{12}$

Based on the above characteristics of Islamic revivalist, the modern Islamic revivalists are divided into two interrelated groups: elements that heal the malaise of the Muslim community. This group consists of Sayyid Jamal al-Din al-Afghani, Muhammad Abduh and Rashid Rida. Second, those who involved with the practical aspects such as leading the Islamic movements or Islamic political parties Abul 'Ala al-Maududi in Pakistan.

Jamal al-Din al-Afghani was born and given a Shi'iate education in Iran. He was well versed in Islamic philosophy and in the shaikhi school of shi'ism that developed in the eighteenth and nineteenth centuries. He was traveling from subcontinent India to Europe, where the famous Arabic newspaper in Pad Abduh also jointly published (the strongest link, a reference in Paris known as "al-Urwa al-Wuthqo" was subsidized by the admirers and an or Islam). This newspaper throughout the Muslim world. In and sent freely to leading figures 

his anti-British polemics, writing especially against British incursion
in Egypt and Sudan. ${ }^{13}$

Afghani's main influence may be traced in a line going back to two Muslim scholars, his Egyptian disciple Muhammad Abduh and the latter's follower Rashid Rida. As Keddie notes that Abduh was the most important of several direct Egyptian disciples and pupils of Afghani who were influenced, among other things by the Afghani's Egyptian teaching of rationalist Islamic philosophy and his use argument for the elite and another for the masses. ${ }^{14}$ In addition, Rashid Rida (1865-1935) was known as the most important pupil of Abduh. He was attracted by Afghani's words but came to know him only at second hand via Abduh. ${ }^{15}$

Muhammad Abduh (1849-1905) was born in a village on the Nile delta in 1849 of a family renowned for its commitments to learning and to religion. His famous contribution among his theological writings is Risalah al-Tawhid, which was based on lectures he gave during his stay in Beirut. In addition, Abduh joined Afghani in publishing newspaper in Paris, as noted by Haddad, which was aimed at following objectives: first, identifying ways in which to rectify the problems of the past which had led to decline. Second, fusing Muslims with a hope of victory and eradication of despair towards their situations. Third, calling to steadfastness in adherence to the principles of the fathers and forebears. Fourth, defending against the accusation levied against Muslims that they can not progress as long as they adhere to the principles of Islam. Fifth, providing information on important political events. Finally, enhancing relations between nations and improving public welfare. ${ }^{16}$

In many ways, Abduh's works amounted to a re-interpretation of Islam for the Muslim world. He was a crucial time when the encounter with Europe was most intense and most urgent. Thus his creative responses both bear the imprint of the heat of the encounter and are tempered by the reality of the weakness and defeat of Muslim nations. According to Haddad, Abduh's ideas continue to shape many of the new generations of Muslims throughout the world. ${ }^{17}$

On the other hands, the modern Islamic revivalists in the twenty century had been more towards the practical leadership of Islamic movements or Islamic political parties. Hasan al-Banna for example, the Egyptian schoolteacher founded the society of Muslim Brother, the most influential movement for reorienting Muslim societies to a pure Islamic order. Hasan al-Banna who grew up in the Egyptian delta town Mahmudiya, transformed an elite intellectual Fashion into popular phenomenon that would profoundly influence the interaction between religion and politics not only in Egypt but throughout the Arab and Muslim world. ${ }^{18}$ 
Banna in fact, shared with the earlier reformers like Jamal alDin al-Afghani and Muhammad Abduh the belief that Muslims' weakness and vulnerability to European domination stemmed from Muslims' deviation from 'true' Islam. He asserts that European civilization consisted of atheism, immorality, individual and class selfishness, and usury. As such it was characterized as a materialistic one that offered Muslims loans in order to gain control of Muslims economies. ${ }^{19}$ Furthermore, al-Banna's writings on religion and politics represent a transition from earlier Islamic revivalists' insistence on their inseparability to a more detailed elaboration of an Islamic polity's functions and underlying principles. According to al-Banna, Islam requires the establishment of a government to prevent anarchy. He was therefore outlining the three basic principles: first, the ruler is responsible to God and the people, and the ruler to him is considered as a servant of the people. Second, the Muslim nation must act in a unified manner because brotherhood among the believers is a principle of the faith. Finally the Muslim nation has the right to monitor the ruler's actions, to give advice to the ruler, and to ensure that its
will is respected

Und Muslimin (Muslim the movement established by al-Banna, Ikhwan in gaining political Brotherhood) has influenced many Muslim society and even Indonesia in the Algeria, Tunisia, Egypt, Jordan, Sudan, who further develops his political one of the successors of al-Banna Egyptian writers, Sayyid Qutb. Hitical vision is the most influential (Signposts on the road), Fi Zilal al-Qur'an such as Ma'alim fi al-Tariq Al-'Adalah al-Ijtima'iyyah fi al-islam (Social justion shade of the Qur'an), circulated and read not only in Egypt but justice in Islam) have been Qutb's view that Islam is the in Egypt but in over the Muslim world. for the world of the twentieth century. Thiate and desirable ideology to all current social and politicntury. To him, Islam has an answer therefore the basis of Ikhwan problems. ${ }^{21}$ His political vision is movement. His great influence has buslimin (Muslim Brotherhood) in Egypt which triggered his been not only in the Muslim society Egyptian government, but equally felt by death penalty by the all over the Muslim world.

Another central figure

twenty century is Sayyidure in the revival of Islam in the modern Islam in fact has formed the 'Ala Maududi. His interpretation of revivalist thought. Maududi who was bon of contemporary Islamic in South India in 1903, has greatly inflorn in the city of Aurangabad thinkers all over the Muslim greatly influenced contemporary Muslim modern era has been evolved world. In fact Islamic revivalism in the thought and theology has been around his own prolegomenon. ${ }^{22}$ His established and led in Pakistan knodied in the movement which he 
Islamic party). This party was established by him self and a number of young ulama and Muslim activists in August 1941.

Maududi advocates an interpretation of Islam, one which aims at mobilizing piety and faith for the purpose of political action. He views Islam as a holistic ideology similar to western ideology in its functions. His notion of Islamic ideology, one of the most prolific and systematic articulations of its kind, has been most influential in giving shape to Islamic revivalism as a distinct reading of Islam, its history, and its purpose across the Muslim world. Besides his books such as Tafhimu al-Qur'an (Understanding the Qur'an) and Risalah-I Diniyat (later translated as Towards Understanding Islam), and his own journal known as Tarjumanu' al-qur'an, which influenced the Islamic revivalism in all over the Muslim world, the Jama'at-I Islami is also depicting his ideology and thought. The party that was led by him until 1972 aimed to preserve the interest of Islam in the political arena and to prevent secular forces from consolidating power. ${ }^{23}$ Undoubtedly the development of Islamic revivalism in Maududi's works and in Jama'at politics provides important insights into the origins and working of Islamic ideology and overall strategy. As a result, any Islamic political party in the Muslim world has been actively involving and participating in elections.

On the other hands, political dimension of Islamic revivalism has been best described by Hussin Mutalib. He outlines the characteristics of Islamic revivalism in general and especially in Southeast Asia. These characteristics include a greater eagerness, to view Islam as way of life, a tendency to create and view Muslim in different part of the world within the framework of global Muslim ummah, certain vigor or assertiveness in espousing Islamic fundamentalist issues, values and solutions, and finally the establishment of movement type bodies or organization aimed at making Muslim better organized and hence more effective in resolving their problem and plight. $^{24}$

\section{Precipitator of Islamic Awakening in Indonesia}

There are at least two factors that lead to the Islamic awakening in Indonesia; international and local factors. International factor suggests that due to the emergence of Islam as potential political power in other Muslim countries, especially Middle Eastern countries. The indirect impact of Middle Eastern government and organizations has probably been greater importance to the development of this awakening. As it has been noted by Mehden that Iranian revolution as milestone to the emergence of Islamic awakening in Indonesia where he mentions that the revolution of Iran has been perceived 
by many Indonesian Muslims as an example of anti-imperialist, antiestablishment, anti-secular victory of Islam. ${ }^{25}$ Furthermore, Islamic awakening also as a result of first, contact with new ideas that have formed the basis for the world wide Muslim resurgence. Contacts with contemporary Islamic thinking have occurred in traditional method, place such as Saudi Arabia, during the pilgrimage and Middle Eastern universities such as Azhar, Baghdad, and Medina. Secondly, wide range of contemporary Muslim literatures finding its ways into Southeast Asia. Explanatory articles, the works of Shariati, Maudı!di, Qutb, and other have reached books stores, religious schools, Muslim students' organizations and universities. ${ }^{26}$

National factors show that after being defeated of political Islam and scared in political sphere, Muslims, especially the supporters of Masyumi were called to concentrate their effort on dakwah (Islamic predication) to pave way to revive people' mental and spiritual development. This led to the establishment of The Indonesian Council for Islamic Predication (Dewan Dakwah Islamiyah Indonesia, DDII) under the leadership of the former leader of Masyumi, Mohammad Natsir in $1967 .{ }^{27}$ In fact there were several predication organizations that revive the people awareness about Islam such as NU, Muhamadiyyah, Persatuan Islam (Islamic Union - Persis) and many others preceded DDII.

Despite the fact DDII was newly established but all Indonesian Muslims felt its influences and missionary. Unlike other predication organizations, DDII has been attributed by two significant attitudes: a belief in the superiority of democracy over the neo-patrimonial forms of rule adopted by the first two president, Sukarno and Suharto, an almost paranoid obsession with Christian missionary efforts as a threats to Islam, and very strong orientation towards Middle East, especially Saudi Arabia. ${ }^{28}$ As such DDII has been viewed as not purely spiritual matter but it is considered as political struggle in the new form. ${ }^{29}$ The DDII was established five years later after the establishment of the Islamic World League (Rabitah al-'Alam al-Islami) in which Natsir himself was one of the vice-Chairmen. Consequently the DDII has been one of the beneficiaries of Saudi's financial contribution.

Notwithstanding with the absence of political Islam, there was a resurgence of ideas, especially Islamic ideas on politics, economics as well as social and legal systems. It was also surprising when in the Not only authored by Indonesian many books on Islam published. from foreign works especially scholars but it was also translation Iran, Egypt, and other Arially from Middle East countries such as house in Bandung was set countries. In around 1982 a publishing emphasizes Islamic teaching up using Iranian name 'Mizan' which eooks, including shi' iate school of thought. 

opened and published Islamic books. The books are not only about Islamic rituals but it contents all disciplines of knowledge such as Islamic society, economics and other problems that Muslims face on justice, equality and so forth. Indeed the books from outside the countries were translated such as the writings of Hasan al-Banna, Abu'l-A'la Mawdudi and several works of Syed Qutb, the former leader of Ikhwan Muslimin (Muslim Brotherhood) from Egypt. Inevitably their thoughts have been influential among the Indonesian Muslims.

Several works of the Iranian intellectuals behind the Iran revolution such as Ali Shari'ati and Khomeini, whose writings were very popular during the revolution in Iran, and a few years later Mustafa Muthahari's work were also translated into Indonesian language. As such the discussions on Islam spread throughout the country. Publications on Islam were easily sold out and Islam thus emerged and championed in intellectual and cultural life of Indonesian middle class. With the availability of some Shi'iite books, Shi'iite school of thought also emerged in Indonesia, especially in Bandung.

Furthermore, there has been cooperation between the ministry of religion and other western universities to send Indonesian Muslim students to study Islamic studies. As such Islamic liberal was also spreading throughout the country. Fazlur Rahman's thought, as noted by Bruinessen, became very influential in Indonesia due to the facts that several Indonesian scholars had studied with him in Chicago and became the propagators and defenders of his ideas. Undoubtedly due to them, many Indonesian young scholars developed his ideas. ${ }^{30}$

In line with the emergence of Islamic liberalism and Shi'ism, the DDII responded to these developments in increasingly hostile manners. It intensely criticized and disturbed the Indonesian forerunners of liberalism and was even axiomatically opposed to Shi'iate teaching. As a result in the later years the DDII's activities were occupied by the perceived threats; from within Islam are Shi'ism and Islamic liberalism and from outside are the Christian and Jewish's threat to the world of Islam. ${ }^{31}$ The DDII uses its own media to convey the message to the mass, which pieviously published weekly known as Media Dakwah (Predication media). Since it was partly sponsored by the outside Muslim world, especially Saudi Arabia, the DDII was also following the Issues of the Muslim world. As such in the late 1980 s, a committee was created in order to organize demonstration of solidarity of the Indonesian Muslims with Issues in Muslim countries such as Palestine, Bosnia, Chechnya and so forth. This committee is known as KISDI, the Indonesian Committee for Solidarity with the Islamic World. On the other hands, this was also very 
concerned with the second outside threats towards Islam, especially Indonesian Muslims.

Its founders belonged to the most fundamentalist group of DDII, were firm believers in Western Jewish and Christian conspiracy to weaken and destroy Islam. As such in the last reign of Suharto, they supported Suharto. Furthermore they extended their support for B.J. Habibie' transitional government and defended him from the forces, leftist and non-Muslims threats, who want to topple down the Habibie's government.

\section{Islamic Intellectualism and Cultural Reformation}

Upon Suharto's domestic political consolidation, in 1978 the government introduced what so-called the NKK - Normalisasi Kehidupan Kampus (Normalization of campus life). It was used to control the students' activities while emphasizing that campuses should be places for studying and not an arena for political discussions. Nevertheless, the NKK has a significant and surprising side effect. Universities in fact, were at the forefront of political discussion and activities. In the 1950s and 60s Indonesian national universities had been controlled by secular nationalist groups and the committed Muslims community was the weaker of the factions in student body. But the late 1970s saw a rapid growth of several religious discourses and led to the domination of Muslims students in the students' organization.

More over, upon the policy of Azas tunggal, all level of Indonesian Muslim citizens turned to pay attention on the mental and spiritual training. Salman mosque at the Institute of Technology Bandung (ITB) is one of the outstanding community of Muslim students who actively propagated Islamic discourses under the supervision of Dr. Imaduddin Abdulrahim, an Indonesian Muslim scholar who had successfully prepared Islamic module for youngsters on Islamic courses including Islamic creed, management and others. Thousands of young Muslims have joined and most of them were university educated and many were university droop-outs. Probably it was the period that invalidated the classifications of Islam among the santri and abangan in Indonesian politics. For the Muslim middle class increased and the nominal Muslims turned to be better and more committed Muslims without any feeling of suspicion.

In retreats, in the 1980 s the Muslim students' activities were motivated to socialize Islam through intellectual and cultural approach. Thus the dakwah groups emerged which was known as tarbiyyah (education). Later on these groups created the Campus Dakwah Institute (Lembaga Dakwah Kampus), a kind of loose umbrella organization for the Dakwah groups. ${ }^{32}$ This process of education 
basically took forms of halaqah (Study circle) which convened in campus mosques and usrah (family) which is more secretive discussion groups met usually in the house of their members. One of this groups was implementing halagah was usually influenced by Muslim Brotherhood (Ikhwan Muslimin), from Egypt as their discussion was focused on the writing of Sayyid Qutb such Ma'alim fi al-tariq (Signposts on the road). This group named its self as Ikhwan Muslimin and currently they claim to be Indonesian branch of the Brotherhood. Most students of this group were quite and apolitical; they primary concerned with individual moral self-improvement. However, the emphasis of discussion was on personal morality and piety, discipline, and an inner rejection of the Pancasila state and un-Islamic practices in modern Indonesia. ${ }^{33}$

Another group was known as Usrah groups affiliated with such the militant Muslims aims at establishing Indonesian Islamic state and Indonesian Islamic arms (Negara Islam Indonesia- NII / Tentara Islam Indonesia -TII) which involved with several rebels in the Sukarno's era. There were also groups which heavily influenced by puritan Islam of Wahhabi in Arabian Peninsula or as it was well known as salafi Islam. This group was mediated trough Saudi-financed Institute for Islamic and Arabic Studies, LIPIA, in Jakarta.

Generally since the 1980 s onwards, discussion on Islam as comprehensive way of life was proliferating in and outside campuses. Dawam Rahardjo, the renown Muslim economist and modernist leader and one of the members of the expert committee of ICMI, who calls the Muslim intellectuals to teach people especially the Muslim community to understand the reality of capitalism and communism. As he asserts that when a Muslim has understood the reality of capitalism and communism he will be able to liberate himself from slavery of materialism. As he argues that "the movement of alternative Muslim development must begin as a cultural movement that liberates human beings from their status as 'komoditi fetisisme' (Commodity Fetishism), to use the world from Marx himself. "... It is liberation from taghut (tyranny) and exploitation of men or institutions (takhiru rogoba or fakhu rogobah) through the use of Qur'an." ${ }^{34}$ Nevertheless this trend was not restricted in the Muslim society only but it extended to the government body as will be discerned shortly in the following paragraph.

Upon the demise of Suharto in 1998, some of these dakwah groups emerged finally as formal cultural and structural movements. Ikhwan Muslimin or tarbiyyah group emerged as Islamic political party known as Partai Keadilan (Justice Party) which further changed its name to Partai Keadilan Sejahtera (Justice and Welfare Party). ${ }^{35}$ The rest groups formed Islamic cultural movements such as pressure groups. 
As such the dakwah groups remain active in every level of society, especially Muslim students. For Students are the future generation that occupies the significant fraction of the society, Indonesia would be producing better and committed Muslims in the future and thus the evidence of Islam, as backbone of the social progress is most visible.

\section{Accommodative Attitude of the New Order Government towards Islam}

Islamization process latter on penetrated into the central power based on the New Order government: Suharto himself, the army and Golkar. The attitude of the government towards Islam has been presented in several cases that the government took side with Muslims' aspiration and interest in the late 1980s and onwards. Undoubtedly the significant change of the government's perception and attitude towards Islam had been doubt by the Muslims, for it was only within short period, four years, Suharto changed his stand towards Islam. Many of Muslim activist as well as scholars were surprised with Suharto's accommodative attitudes. Some political analysts argue that this shift is motivated by the coming election $1993 .^{36}$

However this significant shift from regarding Islamic political tendencies as an enemy of the state to offering the considerable powers of political patronage to the Muslim community would be best explained by three significant scenarios; Islamic awakening; the growth of an educated and prosperous Muslim Middle class; and political mechanism to retain power and the change of Suharto's personal life. First Islamic awakening took place in Indonesia since the Muslims community turned to spiritual development, especially Muslim middle class. They are educated and professional people. This phenomenon is partly related to the government's program of mass education, which the government stipulated that all students must undergo religious education. As discussed earlier that in neutralizing Islamic political tendencies (Political Islam), the government adopted the policy to sponsor the Islamic institutions and establishment of mosques as compensation to the implementation of containment policy for separating religion from politics. This policy aimed at inviting the Muslims' support and participation on the nation development. At the same time Tamara notes that the Muslims were not interested any more in the Western world. Western civilization is no longer regarded as an ideal example for a developing society such as Indonesia. In fact they discussed Islamic ideas on solving the problems that the Muslim community faces such as inequality, unemployment, injustice and so forth. ${ }^{37}$ 
Second, political mechanism to regain the power, where as in beyond the armed forces. In this case, many political observers analyze and he thus extended histo was successfully controlled the army Nevertheless, some Amis control towards Muslims community. ${ }^{38}$ Hefner notes, the presiden political scientists observe as Robert powerful catholic comman a former minister of Defense and towards Muslims ${ }^{39}$ armed forces, were the only influence on his policy being partial and Nevertheless, Hefner criticized this analysis for from the found from his own interview with several Suharto's ministers that Suharto was already aware of and concerned about the growing Islamic resurgence, and thus he and his advisors reflected regularly on event of Islamic revivalism in Iran and Algeria. As such according to Hefner, Suharto saw Muslims as a significant potential force in the near future. ${ }^{40}$

More over, Hefner realizes that Suharto made his rapprochement with Muslim community is partly due to his worsening relationship with the most powerful high-ranking officers in the armed forces, L. B. Murdani who dared to question him about his family's corrupt business activities. As such Suharto launched a ruthless campaign to neutralize Murdani's influences in the armed forces and sought to counterbalance military power with that of the Muslim community. As a result, in the early 1990s Suharto successfully replaced the Catholic general Benny Murdani as head of the armed forces with general regarded as more sympathetic to Islam such as general Feisal Tanjung and other seven key positions reshuffled in the mid 1992.41 As such Islamization in Indonesian politics that was known as 'hijau royo-royo' (literally means all greens) also took place in the armed forces' structure. On the other hands, many middle class Muslims, especially from Alumni of Indonesian University Student Association (Himpunan Mahasiswa Indonesia - HMI) joined Golkar and gained certain significant position in the government. Consequently Islamization penetrated the ruling party and took the same line with greening process of the army, even began advertising its commitment to Islam. ${ }^{42}$

Finally, his personal life changed from being nominal Muslim to be practicing Muslim. As Suharto's confidant, minister of Research and Technology and latter became his successor, B.J. Habibie responded the Muslims suspicion on Suharto's accommodative attitude as Vatikiotis notes that Suharto told Habibie, "I was born a Muslim, I will struggle for the Muslim cause."1 This led to the general assumption that by reasserting his faith, Suharto seemed to be marking a fundamental break with the New Order's disregard for mixing 
religion with politics. ${ }^{44}$ This is again supported by his sincere intention to call his family to perform the pilgrimage, umrah and hajj to Mecca in 1991 and began appearing in Islamic festival at the Istiqlal mosque in 1991, in which there were Islamic tradition exhibition and seminar on Islamic resurgence and its impacts in Indonesia and the rest of the world ${ }^{45}$ Furthermore, Suharto also had also given an authority to the establishment of the first broad-based organization of Muslim intellectuals known as Indonesian Muslims Intellectuals Association (Ikatan Cendekiawan Muslim se-Indonesia, ICMI) in 1990 as further discussed in the following paragraph.

It was at this point Suharto appeared to make good relations with Muslim community since his presidency. As such Suharto's policy took side with Muslim aspiration and interest. It was only in 1989 the House of People representative approved the Islamic court and in 1991 compilation of Islamic laws based on the presidential decree no. 1 year 1991 that cover three significant areas namely marriage, inheritance (Mirath), and endowment (Waqf) was undertaken though non Muslims protested against the decree. ${ }^{46}$ As a matter of facts, the proposal for the Islamic court was forwarded to the government since the Guided Democracy in 1961. Under the new order government the proposal was again shelved due to unsympathetic attitude towards Islam. At the same time, laws of education that recognized the private Islamic schools were approved by the government and thus smoothened the process of Islamization through giving educational opportunity for young Muslims.

Certification of Halal food was also approved only in the late 1980s. When the Majelis Ulama Indonesia (MUI) collaborated with Ministry of Religion and Ministry of Health was allowed to inspect the ingredient of respective product before the endorsement of sold to the public. Latter on the ensured its permissibility before it is first bank based on Shari'ah in government agreed to establish the Indoesia (BMI) in 1991. In fact the Musia known as Bank Muamalat Islamic bank since the $1970 \mathrm{~s}$ and Muslim community proposed the endorsed this proposal but the Islamic Development Bank (IBD) government due to the conflict it was rejected by the New Order and Islamic bank. In fact thet of interest between conventional bank did not yet want to accommodate the New Order government emergence of BMI in 1991 led to the Islamic aspirations. The taknful as an alternative product of the other Islamic projects such as credit system (Bank Perkreditan Rakyat on Profit and Loss Sharing Scheme (PLR) for the small project based attracting the Muslim custorine (PLS). BMI has been successfully not influence by the recent econs and became a reliable bank that was 
research and studies on the Islamic economic system and Islamic banking system in Islamic university and high school institutes.

\section{Emergence of ICMI (Indonesian Muslims Intellectuals Association)}

The establishment of ICMI was the result of diverse social and cultural forces ${ }^{47}$ It was again the reflection of the Islamic awakening. It is different from other Islamic organizations or movements for it was backed and supported by various Muslim groups such as government bureaucrats and technologies, moderate Muslims groups and nongovernment Muslim leaders ${ }^{48}$ However this association was severely opposed by many in the military and some conservative Muslim scholars, the NU led by Abdurrahman Wahid known as Gusdur, the former leader of $\mathrm{NU}$ and a former president. ${ }^{49}$

Nevertheless, ICMI led by B.J. Habibie has successfully contributed to the building of Islamic awareness among the New Order government officers, and the establishment of positive perception on Islam. In fact, Islam during the early New Order was labeled as an extremist and radicalism for it was associated to Darul Islam (DI) who aimed at the implementation of Islamic state and involved in certain rebellions. As such many Muslims, especially among the bureaucrats, were afraid of implementing Islam publicly and to some extent they did not want to be seen as practicing Muslims. ${ }^{50}$

With the establishment of ICMI, Islamic aspiration was given opportunity to take place, as Muslim news paper, Harian Republika was issued in 1992 . Undoubtedly this national daily newspaper was given license due to the support of Suharto. On the other hands, the monitor, weekly and extremely tabloid, owned by Catholic-Gramedia publishing group, which also publishes Jakarta' well read news paper, Kompas, was closed down due to publishing the results of a readers' poll of the most admired public figure. Suharto was placed as the first while Prophet Muhammad was in the eleventh. As a result Muslim community was ruthlessly annoyed and thus the government took its license. ${ }^{51}$

Looking at the ICMI as the Muslim organization that got the president's favor, many nominal Muslim bureaucrats and Golkar cadres joined ICMI. The Islamization took place obviously in the state and society. This was evident in the number of Muslim cabinets and military high-ranking officers increased in 1993 after Suharto being reelected in 1993. 99 percent of the 38 cabinet ministers were Muslims as opposed to the earlier cabinet which was only 60 percent Muslims. ${ }^{.2}$ Furthermore since 1993, Suharto had deployed other think tank 
groups. Previously CSIS (Center for strategic and international studies) was known as the "kitchen" where various ideas to give input for the government decision making, especially in the government political control was cooked. ${ }^{3}$ After the establishment of ICMI, Suharto deployed a different think tank which was regarded as ideas driven from Muslim experts, Center for Information and Development Studies (CIDES). CIDES is a think tank institute established by ICMI leaders in 1993 in Jakarta and it thus has been associated with B.J. Habibie and other Muslim thinkers..$^{54}$

Islam has finally been given an opportunity to enjoy the good relationship and strong patronage with Suharto's government in the 1990s. This patronage was perceived by non-Muslim and some nominal Muslims, especially from NU as the wake of 'sectarian Islam'modernist Muslims whose aim is the establishment of an Islamic state. This awakening has to some extent contributed to the fall of Suharto. As Islamization penetrated to the government body, many groups of the senior non-Muslim and nominal army officers who supported Suharto in the early political consolidation were neglected, especially after the establishment of ICMI. This analysis may contribute to whole and complete scenario that explains why Suharto failed to maintain the power. ${ }^{55}$ Upon the demise of Suharto government, there were Muslim groups who defended Suharto for they believed that Suharto's fall was a political conspiracy of Chinese-Chatolic-Zionist aimed at the destruction of Islam in Indonesia. ${ }^{56}$

\section{Emergence of Fundamentalist Islamic Movements}

One of the silent trends of the religious awakening is the emergence of what the so-called militant, radical, extremist, or fundamentalist movements. This is evident in the emergence of fundamentalist called 'Islamic milit, radical Zionist faction in Israel and then the soand lately in Indonesia. This tical or fundamentalist' in Iran, Algeria reorientation within society trend indicates that there has been a As such radical rely towards appreciating religion.

Hindus in India, Catholicious movements took place among the religious movement even developedistian in Ireland and Radical not refer to one particulareloped in America. Radicalism thus does universal occurrence that can hion in a particular place, but it is According to classical social happen in all-religious traditions. regardless with religious impute orces, radical social movements of defiance. ${ }^{57}$ This is because or not, can be seen as movements behaviors are markedly different their attitudes, views, and social 
Furthermore, according to modern political approach, radical movements, as noted by Jamhari, are not seen as being rebellious, but are rather seen as a natural movement with individual political goals ${ }^{56}$ Nevertheless, a radical Muslims movement as form of Islamic awakening is best explained by anthropologists. For them, it is movement which is inspired by cultural and religious factors and is a response to external power - colonialism or the introduction of a foreign culture. It also use cultural and religious symbols in opposition to the symbols used in mainstream society. As such this movement is form of struggle against and rejection of foreign cultural and power. ${ }^{59}$

In modern era, majority of people are being occupied by the materialism and hedonistic lifestyle, and their life thus have been directed wrongly. The Religious groups who perform their religious practices and enjoin people to do good and forbid them from doing evil have been labeled as 'radical' or fundamental. For this religious practices are only carried out by a small number of people. Since the Islamic awakening is precipitated by the small group of people who re-orientate the society towards Islam, this group may be considered as radical or fundamental group movement.

In Indonesia the Fundamentalist Muslim movements use religious issues, such as the implementation of Islamic shari'ah and the eradication of immorality can be interpreted as a strategy to gain mass support. The small fraction of Muslims who were involved with the previous rebels in Garut, West Java, Sulawesi and Acheh in Sukarno era remained intact up to the present time. As a result, a group of Muslims who propagate the Islamic state of Indonesia were relatively small but very brave and courageous. It was known as fundamentalist Muslim groups. This group lunched the attack against certain government offices due to the policy taken by the government in discrimination of Muslim society, especially political Islam. Nevertheless, the small groups of Muslims who propagated the Islamic Republic of Indonesia are isolated and committed small incidents of violence. It was an attempt to give warning to the government for their discrimination policy. This act of terror in fact started when the sensational affairs of what the government labeled the komando jihad, when a airplane had been hijacked and police station bombed in 1978, the police and military authorities had exercised special alertness in relation to the possibility of other Muslims terrorist groups emerging.

In line with this terror done by the isolated Muslims, the army led by the late General Ali Murtopo, the most influential intelligence army officer and the architect and designer of the New Order's politics, exaggerated the attack. It was widely believed that the army created 'Imran gang', group of people who committed bomb explosion in the Police station at Cicendo in order to discredit Islamic political tendencies. Furthermore, dozens of Muslims were killed 
when soldiers opened fire on a demonstration in 1984 in Jakarta dockland neighborhood of Tanjung Priok. The Spark for demonstration was an accusation by Muslims that several soldiers had dishonored a mosque by entering it without removing their shoes. In the aftermath of the Tanjung Priok killings, Muslims retaliated by burning and bombing banks, stores and even government owned radio and television stations. In the wake of the violence hundreds were arrested including some whose only crime appeared to have been publicly opposing government policies. ${ }^{60}$ Tanjuk priok was considered as the climax of the New Order Government in marginalizing political Islam. For in this events dozens Muslims were killed and jailed due to their involvements in opposing the government including the most famous general $\mathrm{H}$. Dharsono who depended Muslims in the events. ${ }^{61}$

In 1989 an army clash left an estimated one hundreds villagers dead in Lampung. The army initially accused the villagers of being Muslim fundamentalists but latter backed down when it became clear that land rights were at the heart of the matter. More serious for the army that is a renewed insurgency in Acheh province at the northwest Sumatra. The insurgents are ostensibly fighting for an independent Islamic state but again, economic inequality and regional autonomy issues seem to be the real crux of the matter. Since 1989, more than one thousand Acehneses have died, many under circumstances. On the other hands, upon the demise of the New Order Government, there were significant fundamentalist groups. At least there are four fundamentalist groups that aim at the implementation of shari'ah and at making Islam as a basic ideology of their movements. These include Islamic Defenders Front (Front Pembela Islam- FPI), Laskar jihad, Majlis Mujahidin Indonesia, and Hizbut Tahrir.

Islamic Defenders Front (Front Pembela Islam- FPI), was established to combat the evil and fornication spread in the capital city. This movement is led by Habib Rizieq, an Arab descendent who was born in Jakarta. This Muslim organization was initiated by the incident of Tanjuk Priok September 1983, but the formation of this organization was only taken place on 17 august 1998. As a result there were many activities that enjoining good and prohibiting the demonstration against members. The activities include protest and night clubs in the city, disturbing pent, asking them to close several such as adultery, consumptiong people who committed sinful acts this group also aims at the implem alcohols and the like. Furthermore as well as public life. ${ }^{62}$ Due to the tation of shari'ah in their private New Order Government towards accommodating attitude of the in the 1990s up to the demise of Muslims aspiration and interests 
especially Islamic defenders front (FPl) supported Suharto and challenged the Suharto's opponents.

Another fundamentalist Muslim group emerged when the religious conflict took place in Islands of East Indonesia, Maluku where the Christian and Muslims community fought each other in 1999. This tension killed many Muslims as well as Christians. The root cause of this conflict was widely believed that it was due to the inequality of economic prosperity between the two groups. Due to this incident, Muslims community established the so-called "Laskar Jihad", Islamic groups who were ready to holy war in the early months of 2000 by Ahlussunnah Waljama'ah Communication Forum (Forum Komunikasi Ahlussumnah Waljama'ah), which was led by Ja'far Umar Thalib.6. Nevertheless, this movement was dissolved when the conflict disappeared in 2003.

Majelis Mujahidin Indonesia (MMI) also emerged as the fundamentalist Muslim groups. This group was also formed at the same year with Laskar Jihad in Yogyakarta, on August 2000. This group is led by Ahmad Abu Bakar Ba'asyir, one of the founders of Ngruki Islamic boarding school and alleged as one of the leader who ask involve in the newly bombing issues such as Bali and W J. Marriot bombing respectively in 2002 and 2003. This group aims at implementation of Islamic shari'ah. ${ }^{\text {(4) }}$

Finally, Hizbut Tahrir is a political party whose ideology is based on Islam but not registered as Islamic political party that participates in the national election. In fact, it was established to restore the caliphate and to be ruled by God's laws. This group does not agree with liberal democracy. Hizbut Tahrir was established in 1953 in Arab countries especially Lebanon in response to the injunction of God which says, "Let there be among you a group that invites to the good, orders what is right and forbids what is evil, and they are those who are successful." 65

The Party started the first stage in al-Quds in $1372 \mathrm{AH}(1953$ $\mathrm{CE})$ under the leadership of its founder, the honorable scholar, thinker, able politician, qadi in the Court of Appeals in al-Quds, Taqiuddin alNabhani (may Allah's shower His mercy upon him). The ultimate purpose of its establishment is to revive the Islamic Ummah (Islamic community) from the present predicament. As such the group believes that in order to revive the Ummah, Muslim should be liberated from the un-Islamic thoughts, systems and laws, as well as from the domination and influence of the non-Muslim government. What make this group is different from other above fundamentalist movements is the attitude and behavior of the group. Though this group propagates the establishment of an Islamic state but they do not use the terror and destructive method. In fact they believe in educating 
Muslims to be more fearful to God and implement the Islamic teaching gradually.

Its activities have been directed to resume the Islamic way of life and to convey the Islamic da'wah to the world. It means Hizbut Tahrir attempts to shape people behavior in such way that people' affairs in society are administered according to the shari'ah rules and under the leadership of the Islamic state which is headed by a caliph. The members of the party consist of Muslim men and women without any discrimination of being Arab and non Arab, black skin, white or colour one as long as they embrace Islam and carry Islam and adopt its systems regardless of their nationalities, and madhhab (school of thought). ${ }^{66}$

The nature of Hizbut Tahrir's work is to carry the Islamic da'wah in order to change the corrupt society and transform it into an Islamic society. It is done through changing the society's existing thoughts to Islamic thoughts and latter on become the public opinion among the people, who are then driven to implement and act upon them. In addition, this group also works to change the emotions in the society until they become Islamic emotions that accept only that which pleases Allah (swt) and rebel against and detest anything which angers Allah (swt). Finally, the Party works to change the relationships in the society until they become Islamic relationships which proceed in accordance with the laws and solutions of Islam. These actions which the group performs are political actions, since they relate to the affairs of the people in accordance with the Shari'ah rules and solutions, and politics in Islam is looking after the affairs of the people, either in opinion or in execution or both, according to the laws and solutions
of Islam. ${ }^{67}$

The method of the da'wah adopted by this group is based on the seerah, the bibliography of the Messenger of Allah (saw) in his performance during the conveyance of the of Allah (saw) in his
divided into three periods or stages: first, stage of culturing, it
attempts to produce people who believe in the idy of the group, so that theyle who believe in the idea and the method interaction with the ummah the solid group. Second, the stage of and carry Islam, so that the or society, to let the society embrace works to establish it in society takes it up as its issue, and thus establishing government, where the lirs of life. Finally, the stage of Islam generally and comprere the society is enjoined to implement the world. ${ }^{68}$

it as a message to intellectual strup in fact, propagates two significant efforts: first, the thoughts, the incorrect ideas and $K u f r$ (infidel) creeds, systems and their falsehood, defects and contradisified concepts by exposing deliver the Ummah from them and fiction with Islam, in order to 
political struggle, which is represented by a struggle against the Kufr colonialist states which have domination and influence on the Muslim countries. The challenge against colonialism in all its intellectual, political, economic and military forms, involves exposing its plans, and revealing its conspiracies in order to deliver the Ummah from its control and to liberate it from any effect of its influence. In addition, a struggle against the rulers in the Arab and Muslim countries, by exposing them, taking them to task, acting to change them whenever they denied the rights of the Ummah or neglected to perform their duty towards her, or ignored any of her affairs, and whenever they disagreed with the rules of Islam, and acting also to remove their regimes so as to establish the Islamic rule in its place. ${ }^{69}$

More over, though latter events after the American being attacked at September eleventh 2001, were indicated to Fundamentalist Muslim groups for the US Central Intelligence Agency (CIA) accused Muslim terrorists under the leadership of Osamah bin Laden, the leader of 'al-Qaedah' who is responsible for the attack, the public people would perceive that it was a global conspiracy to attack Islam. Indonesia as the biggest Muslim populous had been shown by the CIA to be involved with the international terrorist network under the leadership of certain Islamic movements such as Jamaah Islamiah under the leadership of Abu Bakar Ba'ashir, an Arab descendent who resides in Solo Central Java, Indonesia. As a result Muslims once again became scapegoats of American Intelligence in several bomb explosions such as Bali bomb in 2002 and WJ. Marriott Jakarta in $2003 .^{70}$

\section{Reemergence of Islamic Political Parties After Suharto Era}

Islamic awakening in Indonesia is finally indicated by the reemergence of Islamic political parties. As highlighted in the above passage, the political Islam was marginalized since the Guided Democracy era and it was even worse severely treated in the early New Order era. Though Suharto accommodated Muslims' aspiration and interest and implemented more openness political system in the 1990s, Islamic parties were not yet formed. Upon the demise of Suharto, the demand of reformation continually voiced by all level of pro democracy, Muslim as well as non-Muslim. The emphasis of the reformation was democratization, demilitarization of politics, and abolishment of Suharto's influences, including Nepotism, Corruption and Coalition (Korupsi, Kolusi, dan Nepotisme- KKN) that led to the vulnerable economic and political crises.

As response to the reformation, Habibie announced that the chief priority was to root out the $\mathrm{KKN}$ and to create a clean government. On the political front, he highlights five political laws 
of the previous political system, namely, House of People representative (DPR), the People Consultative Assembly (MPR), political parties, regional administration and election. Furthermore to be more democracy, the law on subversive, which used as means to eradicate the opponents, would be revised immediately. ${ }^{71}$ Nevertheless, being Short lived president, Habibie did his best to implement the above said policy, though the time did not allow him to complete his mission of reformasi. However he successfully established significant alteration to the laws of political system, including abolishment of Azas tunggal (Laws of the Mass organization), conducted the 1999 election, freedom for press and upholding Human rights, and reduction of number of the military in political representatives, especially in the House of People Representative Council.

Upon the abolishment of Azas Tunggal policy, which was created by Suharto in 1985, Indonesia witnessed the emergence of hundreds political parties, many of them along religious lines. ${ }^{72}$ Nevertheless, there were only 48 parties that were qualified to participate in 1999 election. The classification of Islamic and non-Islamic political parties was not easy as the previous political parties. ${ }^{73}$ Presently the Islamic political parties should be recognized through its basic ideological foundation, name, and symbol. If one of these is representing Islam than it could be considered as Islamic political party. As such, of these, 19 are Islamic political parties, which its basic foundation and principle are based on Islam..$^{74}$

The People's Awakening Party (PKB - Partai Kebangkitan Bangsa), the new Party created and led previously by the former chairman of NU, Abdul Raham Wahid (Gusdur) and National Mandate Party, (PAN - Partai Asnamah National), a party created and led by DR. Muhammad Amin Rais, the former chairman of Muhammadiyyah, are not considered Islamic parties for its basis, name and symbol do not represent Islam. However these two parties are associated with Muslim social organizations and relatively rely on support from their own Muslim community.

Out of 19 Islamic parties, there were only few parties gained the support in 1999 election; PPP the long established Islamic party since the New Order secured the significant vote $11 \%$. The Crescent and Star Party (Partai Bulan Bintang- PBB), which was claimed as the Masyumi's successor, gained only $2 \%$, and the Justice Party (Partai Keadilan- PK), which represented what was known Lembaga Dakwah Kampus (LDK), secured only $1.5 \%$, and the other Islamic parties received even less vote. Nevertheless, The PKB and PAN which were known as Nationalist party but led by the prominent Muslim leaders secured more votes with respectively $13 \%$ and $7 \%$. While the rest votes were accumulated in the two other New Order parties, 
Indonesian Democratic Party (Partai Demokrasi Indonesia - PDI-P) under the leadership of Megawati won the greater votes with $35 \%$ and Golkar, the New Order political party was still gaining higher vote with $23 \%$.

Not surprisingly, the latest election 2004 resulted the same position, where Islamic parties were defeated. But it is interesting to note that Justice and Welfare Party (PKS) which previously known as PK, gained more votes compared to 1999 election. It is partly because of its successful present elected member of the house to convince people as clean and uncorrupted members. While the rest Islamic parties, except PPP, secured less votes and thus unqualified to participate in the next election. PKB and PAN secured more less the same result as the 1999 election. Golkar won the more votes than that of PDI-P. On the other hands, The New party known as Democrat Party (PD) surprisingly secured more votes. It is partly the figure of its presidential candidate is very charismatic general whom people admire for his intellectuals and determinant. Despite fact that the 1999 election did not reside with Islamic parties, It gave the Middle class Muslim controlled the parliament. The middle classes Muslims were represented in the HMI alumni in several parties namely PBB, PAN, PPP and especially Golkar who had undergone the Islamization (the "green" members)..$^{75}$

This election to some extent depicted the scenario of Indonesian Muslims. Though there was Islamic awareness among people, but this awareness is limited to personal life, and not yet to the level of establishment of Islamic state. As such the increasing awareness could not be called as Islamic revivalism, it is just part of its phenomena and may be called as an Islamic awakening. Secondly the Indonesian Muslim Scholars have different opinions on the importance of Islamic state; the softer line conservative and some Modernist Muslims such as Abdurrahman Wahid, the former leader of the NU, Nurcholis Majid, the propagator of Islamic liberal, and lately even Dr. M. Amin Rais, the former leader of the modenist Muslims Muhammadiyyah, did not agree with the formation of Islamic state. ${ }^{76}$ On the other hands, the other modernist Muslim groups such Islamic defenders fronts (FPI), KISDI, DDII, and others are in the opinion of the importance of the Islamic state. Finally many Muslims, especially nominal Muslims in the urban area rejected the Islamic political party, as widely believed that if people vote the Islamic party, then they would not have freedom to enjoy the hedonistic life.

Moreover, many Muslim scholars commented the result of 1999

election as the defeat of formal Islam that indicates that Islamic political parties are not the choice of Indonesian Muslims. However the substantive Islam remained leading in Indonesian politics. This is evident in the several decision-making processes in the house of the 
representative (DPR). Nurcholis Majid shared the same view with Azyumardi Azra, Muslim scholar and the rector of National Islamic University, on the lack of relevancy of formality and symbols of political Islam in present Indonesia. Azra argues that "Most Indonesian Muslims are learning towards what I (Azyumardi Azra) call "substantive Islam" rather "formalistic Islam"."

Since there was not party won absolute majority, the election of new president was to be result of complicated negotiations between the parties and other relevant actors, including military. Amin Rais urged Islamic parties to forge alliance between PAN and the three major parties, PPP, PBB and PK known as the Central Axis (poros tengah), which aims at preventing Megawati from becoming a President. Megawati was prevented was because of several reasons; in term of gender, for there was strong objection to the idea of woman becoming president. Secondly it was in fact the primary issue of the high proportion of Christian in Megawati's PDI-P and doubt about her own Islamicity. Finally Abdurrahman Wahid was proposed to become president by the central axis. Nevertheless, Wahid did not able to maintain his presidential position due to the failure of tackling the multiple domestic crises from politics, social as well as economy. As a result he was later impeached by the house of representative (DPR), which was again controlled by the central axis in 2001, for he was involved in Bulog gate, and other corruptions among the circle of the president. This again led to the unrest and severe demonstration conduct by the Wahid's supporters.

With fall of Wahid, Megawati was appointed as the fifth president until 2004. Megawati was also supported by the Central Axis for being obliged in accordance with the constitution, and no other choice to prevent the chaos among the Megawati's supporters. Axiomatically the central Axis has been playing significant roles in determining Indonesian politics post-Suharto era. Despite the fact, Islamic political parties did not win the election, but they are very determinant factor in decision-making process, especially in the house of representative and it thus demonstrated the ability of Islam to
present itself as a potent political force.

In line with the reformation of the 1945 constitution, the discussion on the constitution went on from 1999 to 2002. Muslims implementationded to discuss again the Jakarta charter and the modernist Muslim of shari'ah. However because the softer line Nevertheless, this prol the parliament, the proposal is not accepted. accepted in the regionosal of the implementation of shariah was Acheh were given autonal province level. In this case Makkasar and 


\section{Conclusion}

As it is evident in the above arguments, that in the last decade of Suharto's government, he provided opportunity for the rejuvenation of Cultural Islam. As such many Dakwah groups emerged among the Muslim society within and without the university's campuses. The DDII, as Masyumi's cultural successor, has been one of the most significant groups that yielded cultural transformation among Muslims that is known as Islamic awakening.

Islamic awakening in Indonesia was to some extent influenced by Islamic resurgence in other Muslim world, including Iran, Algeria, Egypt and even the Muslim scholars in the west. The awakening in Indonesia was partly because of the Muslims' anxiety of modern life. They, especially Muslim students in campuses, conducted several dakwah groups known as halagah, usrah and later on under the institution known as the Lembaga Dakwah Kampus (LDK) to provide spiritual and mental training. As such in the late 1980s, the increasing number of middle class Muslims successfully attracted Suharto's attention. Suharto began to accommodate the Muslims' aspiration and interest through the approval of Islamic court and recognition of private Islamic schools and extending the blessing permission to the Muslims intellectuals in the establishment of Indonesian Muslims' Intellectual Association (ICMI) in 1991, chaired by B.J. Habibie.

With rise of ICMI in Indonesian politics, the Islamization penetrated the New Order government, including the military and Golkar known as greening process (hijau royo royo). On the other hands, with the decline support from the secular nationalist army, which was heavily influenced by nominal and Christian generals, Suharto reshuffled the high-ranking army officers and appointed Muslim generals. As a result Suharto offered the special patronage to Muslim groups.

The fall of Suharto's government in 1998, triggered to the proliferation of Fundamentalist Muslim groups and Islamic political parties. Due to open political system implemented by Habibie, there are Fundamentalist Muslim movements appeared in response to the instability and escalation of evils among the society. Laskar Jihad, Majelis Mujahidin Indonesia and Front Pembela Islam and Hizbut Tahrir represent these groups. They aim at the implementation of shari'ah. Furthermore, upon the abolishment the azas tunggal, 19 Islamic political parties emerged and qualified to participate the 1999 elections. Despite the fact the election did not favor for the Islamic parties, Islamic political parties which took alliance with Amin Rais's PAN, formed the central axis and later play determinant roles in decision making process in the house of representative (DPR). Indeed the Islamic awakening obviously influenced the Indonesian politics in the 1990s and post Suharto era. 


\section{Notes}

1 Ali Rahnema (ed.), Pioneers of Islamic Revival, New Jersey: Zed Books Ltd. 1994 , p. 5.

2 Ibid.

3 Ibid.

4 lbid.

5 Ibid., p. 6

6 Ibid.; see also Kalim Siddiqi, Stages of Islamic Revolution, London: the Open Press, 1996.

7 Ibid., p. 6.

8 Ibid., p. 7.

9 S. Abu 'Ala Maududi, A Short History of the Revivalist Movements in Islam, Lahore: Islamic Publication (PVT) Limited, $8^{\text {th }}$ edition, 1988, p. 35. Ibid., p. 6.

Ibid.p. 38.

12 Ibid., pp. 38-39.

13 Nikki R. Keddie, "Sayyed Jamal al-Din al-Afghani", in Ali Rahnema (ed.) Pioneers of Islamic, p. 19.

14 Ibid., p. 25.

15 Ibid., p. 20.

16 Yvonne Haddad, "Muhammad Abduh" in Ali Rahnema, Pioneers of Islamic, p. 33.

17 Ibid., p. 60.

18 For his bibliography, see Hasan al-Banna, Memoirs of Hasan al-Banna Shaheed, Karachi: International Islamic Publishers, 1981; Richard P. Mitchell, The Society of the Muslim Brothers, London: Oxford University Press, 1969;Hasan al-Banna, Majmu'at rasail al-Imam al-Shahid Hasan alBanna, Beirut: Dar al-Andalus, 1965; David Commins, "Hasan al-Banna (1906-1949)", in Ali Rahnema (ed.), Pioneers of Islamic, pp. 125-153.

David Commins, "Hasan al-Banna", p. 133. Ibid., p. 135; see also Hasan al-Banna, "Mushkilatuna fi Daw' al-Nizam al-Islami," in Majmu'at Rasail, pp. 358-9, 366.

21 Charles Trip, "Sayyid Qutb: the Political Vision", in Ali Rahnema (ed.), Pioneers of Islamic, pp. 154-183; Sayyid qutb, Ma'alim fi al-Tariq, Cairo: Dar al-Shuruuq, 1988; Al-Adalah al-Ijtima'iyyah fi al-Islam, Cairo: Dar alShuruuq, 1980.

22 Seyyed Vali Reza Nasr, "Mawdudi and the Jama'at -I Islami: the origin, Theory and Practice of Islamic revivalism", in Ali Rahnema, Pioneers of Islamic, pp. 98-124. For further reading on the influences of Maududi's thought on Islamic movements see John 1. Esposito, The Islamic Threat: Myth or Reality?, New York: Oxford University Press, 1992; Emmanuel Sivan, Radical Islam: Medieval Theology and Modern Politics, New Haven:
Yale University Press, 1985.

${ }^{23}$ Seyyed Vali Reza Nasr, "Mawdudi and the Jama'at-I Islami,", p. 112. 
24 Hussin Mutalib, Islamic Revivalism in ASEAN Countries, in Asian Survey, vol. XXX, no. 9 September 1990, p. 878.

${ }^{25}$ Fred R. Von der Mehden, Two Worlds of Islam: Interaction between Southeast Asia and the Middle East, Gainesville: University Press of Florida, 1993, p. 101.

26 Ibid., p. 102.

27 See Robert W. Hefner, Civil Islam, pp.106-116.

28 Martin van Bruinessen, "Genealogy of Islamic Radicalism in Post-Suharto Indonesia", in South East Asian Research, Vol. 10, No. 2, July 2002, p. 123; Robert Hefner, Civil Islam, p. 107.

29 Harold Crouch, The Army and Politics, pp. 167-171.

${ }_{30}$ Martin van Bruinessen, "Genealogy of Islamic", p. 126.

${ }^{31}$ Ibid., p. 127.

32 Mathias Diedersich, "A Closer Look at Dakwah and Politics in Indonesia: The Partai Keadialan" in Archipel 62, Paris, 2002, p.103; see also Azyumardi Azra, Islam Substantif, Bandung: Mizan, 2002.

${ }^{33}$ Ibid., p. 133.

34 Dawam Rahardjo, "Islam Mendayung Antara Dua Karang: Sosialisme and Kapitalisme', in Prisma no ekstra 1984; see also M. Nasir Tamara, Indonesia in the Wake of Islam 1965-1985, Malaysia: The Institute of Strategic and international Studies, 1986, pp. 8-9

35 Mathias Diedersich, "A Closer Look", pp. 101-115.

36 For further reading on the accommodative attitude of the New Order government, see Bahtiar Effendy, Islam and the State in Indonesia, Singapore: ISEAS, 2003, pp. 149-192.

${ }^{37}$ M. Nasir Tamara, Indonesia in the Wake, p. 9.

36 Abdurrahman Wahid, known as Gus Dur was in the opinion of full support from the military to Suharto and Suharto thus attempted to gain other Support from Muslim societies.

Robert W. Hefner, "Islam and Nation", p. 49.

Ibid, p. 50

"Michael Vatikiotis, Indonesian Politics, p. 209; Robert Hefner, Civil Islam, p. 151.

12 Robert W. Hefner, "Islam and Nation", p. 66; "Islamization and Democratization in Indonesia" in Robert W. Hefner, and Horvatich, Muslim Southeast Asia, p. 89; see also Kikue Hamayotsu, "Islam and National Building in Southeast Asia: Malaysia and Indonesia in Comparative Perspective", in Pacific Affairs, Vol. 75, No. 3-Fall 2002, p. 370

43 Michael R. J. Vatikiotis, Indonesian Politics., p. 132.

s Ibid., p. 133.

s Sudirman Tebba, Islam Menuju Era Reformasi, Yogyakarta: PT Tiara

* Wacana Yogya, 2001, p. xv. Ibid., p. xiv. 
47 For further reading on the establishment of ICMI see Nasrullah Ali-Fauzi (ed.), ICMI: Antara Status Quo dan Demokratisasi, Bandung: Mizan, 1995; Adam Schwarz, A Nation in waiting, pp. 176-193. Douglas E. Ramage, Politics Under Suharto, pp. $75-121$.

48 Adam Schwarz, A Nation in Waiting, p. 177.

49 Ibid., 185-188; Douglas E. Ramage, Politics under Suharto, pp. 112-118 and 138 - 144, Ibid.

Ibid., pp. 87-89.

Leo Suryadinata, Interpreting Indonesian Politics, Singapore: Times Academic Press, 1998, pp. 239-249.

Dewi Fortuina Anwar, "Policy Advisory Institutions: "Think Tanks"'", in Richard W. Backer, M. Hadi Soesastro, et all (Eds.), Indonesia: The Challenge of the Change, Singapore: Institute of Southeast Asian Studies, 1999 , p. 239.

54 Ibid., p. 245

55 Fur further explanation, see Adam Schwarz, Nation in Waiting, pp. 308366; Robert Hefner, Civil Islam, pp. 167-213; See also Bilveer Singh, Succession Politics in Indonesia, London and New York: Macmillan Press Ltd, 2000, pp. 99-154..

56 Robert Hefner, Civil Islam, pp. 201-207.

57 See for example, Doug McAdam, Political Process and the Development of Black Insurgence, 1930-1970, Chicago: The University Chicago Press, 1999. Jamhari, "Mapping Radical Islam in Indonesia", in Studika Islamika, Vol. 10, No. 3, 2003, p. 19

59 Ibid., p. 20.

60 Adam Schwarz, A Nation in Waiting, p173.; Amnesty International, Indonesia: Arrests of Muslim Activists Relating to the Tanjung Priok Incident of 12 September 1984', London: July 1985; Michael Vatikiotis, "Islam's Hidden Warriors", in Far Eastern Economic Review, 23 February 1989; Adam Schwarz, "Deadly Suspicion", in Far Eastern Economic Review, 25 July 1991, pp. 16-20.

61 It was widely believed that this incident was orchestrated by the secular army general to discredit the Muslim society. L. B. Murdani, a Catholic general, who used to discriminate political Islam in the early New Order era. Jamhari, "Mapping Radical", pp. 10-12. For further reading on Laskar Jihad see Michael Davis, "Laskar Jihad and The Political Position of Conservative Islam in Indonesia", in Contemporary Southeast Asia, Vol. 24, No. 1 April 2002, pp. 12-32. Jamhari, "Mapping Radical", pp. 14-15 Qur'an : 3:104 See http://hib-ut-tahrir.org/english/english.html, visited on March 07, 

Ibid., see also http://hiz
visited on March 07, 2006.

68 Ibid.

69 Ibid.

70 It has been widely believed that the bomb was set up by the CIA while the Muslims became scapegoats of the events. For the kinds of bombs were impossible to be owned by developing countries such as Indonesia and other Muslim countries. As the former leader of Indonesian Intellegence, ZA Maulani asserts that this type of bomb is only available in the USA. See Republika July 2002.

${ }^{71}$ For further reading on the reformation, see Ahmad Watik Pratiknya, Umar Juoro and Indria Samego (eds.), Pandangan dan Langkah Reformasi B.J. Habibie, Jakarta: PT RajaGrafindo Persada, 1999; Bilveer Singh, Succession Politics, pp. 155-236.

72 There were 126 parties registered in 1999. See Ibid., pp. $171-181$; Adil: Tabloid Berita Mingguan Vol. 13, No. 67, 30 December 1998 - 5 January 1999 , p. 8.

${ }^{73}$ In the Old Order Era, Islamic parties were based on Islam. It could be seen from its ideological and basic foundation of the parties such as Masyumi, the NU, Persatuan Tarbiyah Islamiyah (PTI), and Partai Syarikat Islam Indonesia (PSII). In the early New Order there were NU, PTI, PSII and Partai Muslimin Indonesia (PMI), which later on fused in the United Development Party (Partai Persatuan Pembangunan, PPP). The basis of the respective party was Islam except PPP which later on based on Pancasila and thus the Islamic political party did not exist totally since early the 1980 s.

74 The list of Islamic political parties, see Sudirman Tebba, Islam Menuju, p. xx-xxi.

75 R. Milliam Liddle, "The Islamic Turn in Indonesia: A Political Explanation", in The journal of Asian Studies, vol. 55 no. 3, August 1996, p. 630 .

76 Nurcholis Majid is known as 'Cak Nur', graduated from Chicago University and has been known as the propagator of Islamic liberal and secular Islam. As he proposed in the 1970s the separation of politics from the religion as he expressed it in his popular essay "Islamic Yes: Political Islam NO".

$\pi$ Azyumardi Azra, "The Megawati Presidency: Challenge of Political Islam" in Hadi Soesastro, Anthony L. Smith and Han Mui Ling (Eds.), Government in Indonesia: Challenges Facing the Megawati Presidency, Singapore: ISEAS, 2003, p. 63. 